Journal of Extension Education

Vol. 29 No. 1, 2017

DOI:https: / / doi.org/10.26725/JEE.2017.1.29.5787-5796

\title{
Information Seeking Behaviour of Shrimp Farmers and their Perception towards Technology Dissemination through Mobile Phones
}

\section{P.R. Anand ${ }^{1}$ and M.Kumaran ${ }^{2}$}

\begin{abstract}
A study was conducted among the shrimp farmers to ascertain their information seeking behaviour and perception concerning extension service through mobile phones. The findings indicate that the farmer respondents were of the perception that mobile phone-aided extension service is a viable, expedient, prompt, cost-effective and novel approach. Further they expressed that a dedicated mobile app on shrimp farming with dynamic content modules on 'disease diagnosis, calculations for water quality corrections, feed management, pond risk management and post your query 'would be very useful for farmers and extension workers to update their capacity and sharing of field experiences. Therefore, developing a mobile app on shrimp farming, incorporating the above features would enhance the access to quality information and minimise the information gap among the shrimp farmers.
\end{abstract}

Keywords : Aquaculture extension; m-extension; knowledge dissemination; mobile app.

\section{INTRODUCION}

Shrimp aquaculture, rearing
of shrimps in brackishwater under controlled conditions is being practised in the maritime states along the coastal line of India. Shrimp farming is taken up on a commercial mode as $90 \%$ of the production is exported, earning about Rs.22,000 crores as foreign exchange. Being a delicate organism, shrimp requires quality rearing medium, optimum feeding and health care. Shrimp farming is subject to several production risk factors from pond preparation to harvest and the farmers should have adequate knowledge and skill in Better Management Practices (BMPs) to prevent and manage them. Therefore information is a critical resource in operation and management of shrimp farming. Estimates indicate that 60 percent of farmers do not access any source of information for the advanced agricultural technologies resulting in huge adoption gap. In India, there are about 120 million farm holdings and

1-Ph.D Scholar and 2- Principal Scientist, ICAR-Central Institute of Brackishwater Aquaculture, 75, Santhome High Road, Chennai - 600028. 
the number is growing year by year. To provide at least one village extension personnel to 800-1000 farm families, the requirement of field level extension personnel is estimated to be about 1.3 to 1.5 million, against the present availability of 0.1 million (Planning Commission, GoI, 2007). According to estimates, on an average a public worker personnel spends 40 minutes per year for a farmer (Dileepkumar, 2012). There is a gap between the extension agents and farmers due to poor access and ineffective service (Mruthunjaya \& Adhiguru, 2005). To minimize this gap many computer and internet based projects for providing rapid extension services were initiated but such initiatives have not been very successful, as farmers were either illiterate or not culturally attuned to access information through the internet (Ganesan et al.2013).

In this scenario, the increasing penetration of mobile phone networks and mobile phone usage in India presents an opportunity to use it as a tool for extension service. Review on mobile phone based extension indicates that introduction of mobile phones for information sharing decreased the market price dispersion and wastage, significant improvements in knowledge of farmers, provided greater convenience on time saving, reduced grain price dispersion across markets by a minimum of 6.4 percent and reduced intra-annual price variation, enhanced the access to technology information and reduced communication costs for the farmers. Similarly agricultural extension services delivery through mobile phones has significantly improved the amount, quality and speed of the services which in turn led to higher production level and income status, and reduced the gap between the better off and disadvantaged farmers. Powerful means of increasing access to quality information to farmers and mobile based agro-advisories would play a significant role in reducing the information gap and information asymmetry between the farmers. In this context, the present investigation was undertaken to know the perception of shrimp farmers in using mobile phones for technology dissemination, required modules and preferred format of information delivery.

\section{METHODOLOGY}

This study was taken up in Tamil Nadu, Andhra Pradesh and Odisha states in the east coast and Gujarat, Maharashtra and Karnataka states in the west coast considering their shrimp farming area and production. A proportionate sample size of 210 in the east coast and 120 in the west coast was chosen in line with the number of farmers operating shrimp culture in the respective states. A perception analysis was done following the methodology suggested by Omotesho et al. (2015) and Osondu \& Ibezim, (2015) to know the 
sensitivity of the respondents towards technology information dissemination through mobile phones for shrimp farming, information modules and the format of delivery. The farmers rated each of the 12 selected mobile phone extension attributes for importance on a three-point scale (strongly agree-agree-disagree). The ratio of respondent's total score to the maximum possible score multiplied by 100 formed the perception index. A comprehensive questionnaire was developed and pre-tested for the primary data collection. Descriptive statistics and student t-test were employed to consolidate and interpret the data.

\section{FINDINGS AND DISCUSSION}

\section{Information Seeking Behaviour of Shrimp farmers}

The information seeking behaviour of shrimp farmers given in Fig-1 indicates that three-fourths of east coast $(73.20 \%)$ and majority of west coast (58.30\%) respondents depend on the technicians of feed and other input companies and independent consultants for technical guidance and sourcing quality inputs. In shrimp farming, all the critical inputs (seed, feed etc.) were supplied by the private companies and they had their field staff to aid and advise the farmers. Even though their services were paid indirectly through the cost of inputs they were trusted by the farmers due to their easy accessibility, regular contact and providing pond specific advice which were not quite possible for the government departments. However, in case of west coast, where the area under farming was less and the technicians were also a few, the farmers (61\%) had to depend on the fisheries departments to source inputs and services which is evident in their information seeking. This could be the reason for $52 \%$ of farmer respondents in the west coast consulting on-line sources for technical information. Similarly majority of the east $(60 \%)$ and west $(72 \%)$ coast farmers consulted progressive peers for practical solutions and triangulate the information obtained from other sources for validation. NSSO(2005) had reported that the most popular information source of farm households for accessing information was 'other progressive farmers', followed by 'input dealers'. Shrimp farming is relatively high investment and high risk enterprise farmers need specific information which was possible mostly from the fellow progressive farmers and input technicians. Institutional sources due to their limited manpower budget and pre-occupation with welfare, regulatory and administrative functions could not concentrate more on providing technical advisory services to the farmers. Earlier studies reported similar findings (Kumaran et al. 2007 and Swathilekshmi et al. 2009) on the information seeking behaviour of shrimp farmers. 


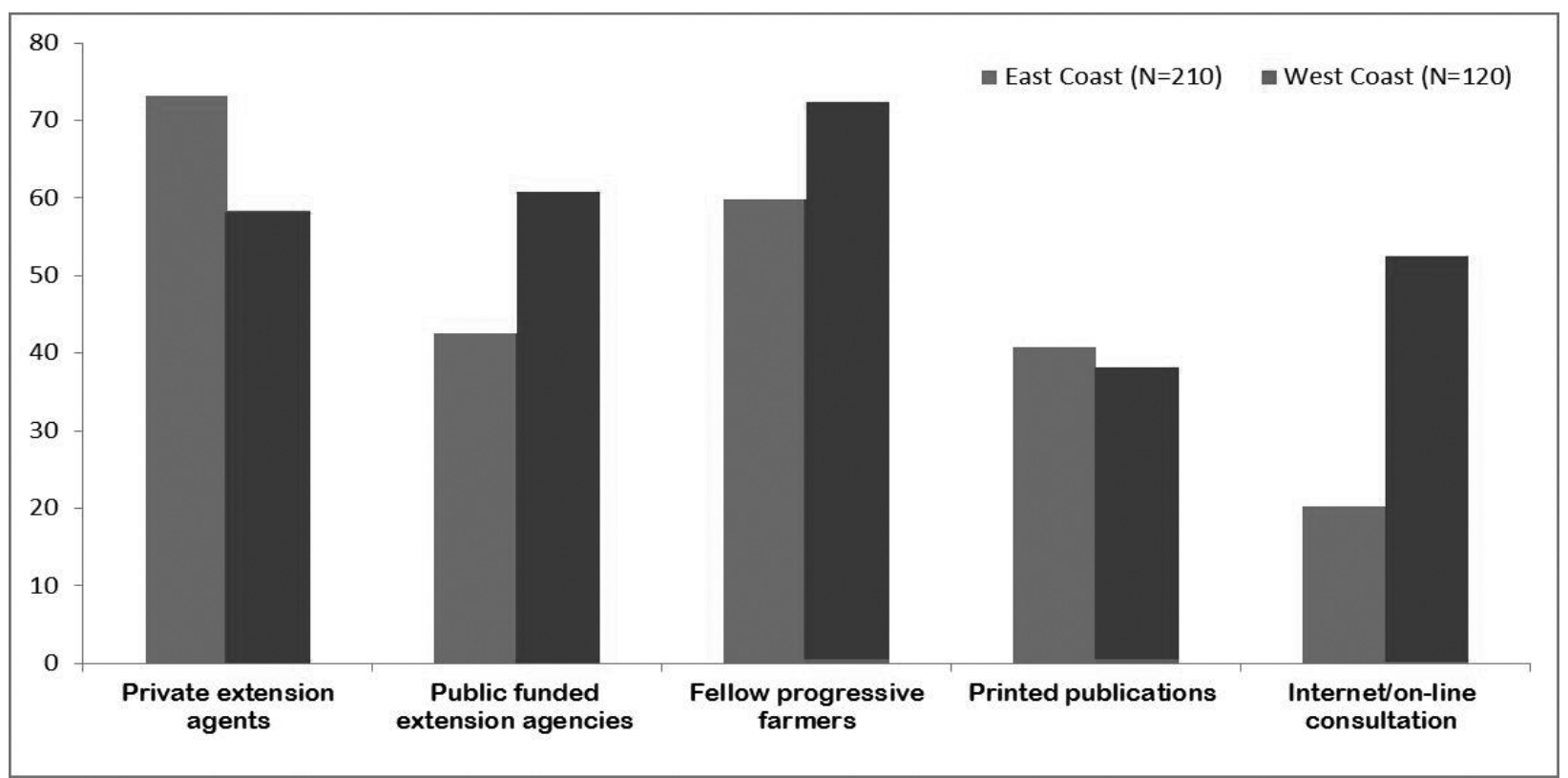

Fig. 1 : Information Seeking Behaviour of Shrimp farmers in \% ( $N=330)$

Mobile phones and networks available with shrimp farmers

The growth of mobile phones in India has been phenomenal during the last one decade. Internet and Mobile Association of India (IAMAI) reported that India had 934.6 million mobile phone subscribers in 2017. The number of mobile internet users in India is projected to double and cross the 300 million mark by 2017 and the number of smartphone users is expected to reach 369 million by 2018. The data shown in Table-1 indicate that $66 \%$ of the shrimp farmers were smart phone users which would mean that they were mobile internet users. Most of them (63.83\%) used Android platform which should be kept in mind while developing any mobile phone based application for shrimp farmers. Most of them (87\%) had networks other than
BSNL and $91 \%$ of farmers preferred English as the language of interaction. Shrimp farmers were relatively better educated and afford to have advanced mobile phones, therefore, mobile phone based information exchange could be a viable strategy to provide information and services and interact with shrimp farmers.

\section{Perception of Shrimp Farmers about Mobile phone as an Information Channel}

The respondents' sensitivity towards mobile phone as a potential medium for technology dissemination and forging technology-extensionfarmers-input and market linkage was attempted and results are presented in Table-2. Majority of the respondents (66$75 \%)$ perceived that mobile phone could be the potential medium of information 


\section{Table1.}

Mobile Phone Infrastructure (Type and Networks) Available with Farmers

$(n=310)$

\begin{tabular}{|c|l|c|}
\hline S1.No. & \multicolumn{1}{|c|}{ Mobile } & Percentage \\
\hline 1 & Mobile handset model & 34.05 \\
\hline & Basic Handsets & 65.95 \\
\hline & Smart phone & 63.83 \\
\hline 2 & Mobile phone platform (Operating system) & 04.26 \\
\hline & Android & 31.91 \\
\hline & iOS & \\
\hline & Others & 13.00 \\
\hline 3 & Network service provider & 87.00 \\
\hline & BSNL & 91.00 \\
\hline 5 & Other private networks & 09.00 \\
\hline & Preferred language for information & \\
\hline & English & Vernacular \\
\hline
\end{tabular}

exchange and $\mathrm{m}$-extension services would be the information management mode especially for shrimp in the days to come (83-85\%). Further, they perceived that at present, most of the on and off-farm information in the supply chain shared was mainly through mobile phone (8494\%). Anbarasan \& Karthikeyan (2014) also reported that mobile phones with camera facility can be used to access extension advices from the experts for effective farming. Majority of shrimp farmers had perceived $(67-87 \%)$ that M-extension would be rapid, timely and cost effective. Moreover, majority (59$71 \%)$ felt that mobile phone provide scope for two-way interaction between the users and aid in obtaining feedback from the field and mobile phone has the scope to carry a customised content to the audience (58-85\%), comprehensive modules on a subject matter can be delivered through mobile phone (60-71\%). However, only $40-42 \%$ of the respondents perceived that mobile phones substitute physical meetings where the farmers could interact with researchers in person. Further, the respondents asserted that they were even willing to pay for the information and advisory through mobile phones (63-66\%). The perception of farmer respondents same irrespective of the state they belong to $(P>0.05)$. This indicates the fact that farmers were looking for problem solving information and wish to get it even paying a cost. The findings show that farmers were of the opinion that mobile phone extension is convenient, rapid, cost-effective and efficient. 
Table 2.

Perception of Shrimp Farmers on Mobile Phone as Potential Medium of Information Dissemination

\begin{tabular}{|c|c|c|c|}
\hline $\begin{array}{l}\text { S1. } \\
\text { No. }\end{array}$ & Attributes of Mobile Phone & $\begin{array}{l}\text { East coast } \\
\text { Mean } \\
\text { perception } \\
\text { score } \\
(\mathrm{N}=210)\end{array}$ & $\begin{array}{l}\text { West coast } \\
\text { Mean } \\
\text { perception } \\
\text { score } \\
(\mathrm{N}=120)\end{array}$ \\
\hline 1 & $\begin{array}{l}\text { Mobile phone is an effective tool for } \\
\text { dissemination of technology information on a } \\
\text { rapid mode }\end{array}$ & $84.76 \pm 9.67$ & $77.50 \pm 9.87$ \\
\hline 2 & $\begin{array}{l}\text { Mobile phones are being used for technical } \\
\text { information dissemination in agriculture and } \\
\text { weather forecast. }\end{array}$ & $47.14 \pm 12.84$ & $43.33 \pm 14.36$ \\
\hline 3 & $\begin{array}{l}\text { Mobile phones aid in providing timely } \\
\text { information }\end{array}$ & $78.09 \pm 9.54$ & $67.50 \pm 11.33$ \\
\hline 4 & $\begin{array}{l}\text { Mobile phones provide scope for sending } \\
\text { feedback and field problems }\end{array}$ & $71.42 \pm 8.96$ & $59.17 \pm 12.36$ \\
\hline 5 & $\begin{array}{l}\text { Comprehensive and value added information } \\
\text { can be given through mobile phones. }\end{array}$ & $70.95 \pm 9.64$ & $60.00 \pm 6.74$ \\
\hline 6 & $\begin{array}{l}\text { Customised content can be delivered through } \\
\text { mobile phones }\end{array}$ & $84.76 \pm 6.26$ & $57.50 \pm 7.64$ \\
\hline 7 & $\begin{array}{l}\text { Mobile phones could provide dynamic } \\
\text { information access on mobility and it is } \\
\text { interactive too. }\end{array}$ & $86.67 \pm 3.65$ & $80.08 \pm 3.64$ \\
\hline 8 & $\begin{array}{l}\text { Mobile phone conversations substitute physical } \\
\text { meetings }\end{array}$ & $42.38 \pm 12.51$ & $40.00 \pm 14.65$ \\
\hline 9 & $\begin{array}{l}\text { The information delivery through mobile phone } \\
\text { is cost effective }\end{array}$ & $86.67 \pm 5.57$ & $71.67 \pm 6.24$ \\
\hline 10 & $\begin{array}{l}\text { Mobile phones are the medium of information } \\
\text { sharing among the farmers/technicians / } \\
\text { consultants to get technical information }\end{array}$ & $94.28 \pm 2.14$ & $84.17 \pm 5.32$ \\
\hline 11 & $\begin{array}{l}\text { Mobile phone aided information system would } \\
\text { be future model of farm extension service }\end{array}$ & $85.71 \pm 6.32$ & $83.00 \pm 6.21$ \\
\hline 12 & $\begin{array}{l}\text { Willing to pay for accessing information through } \\
\text { mobile phone. }\end{array}$ & $62.85 \pm 3.32$ & $66.00 \pm 2.24$ \\
\hline & Mean perception score & $74.64 \pm 16.44$ & $65.83 \pm 14.55$ \\
\hline
\end{tabular}


Information Requirements and Format of Delivery through Mobile phones

The information requirements (content), period and frequency of delivery through mobile phones expressed by the farmers are given in Table-3. Market intelligence (80.40\%), growth assessment, feeding, water quality monitoring, disease preventive measures (78\%), pond preparation protocols $(77 \%)$, seed availability, seed selection and nursery rearing (74\%) were the information requirements expressed by the shrimp farmers.

It is observed that the frequency and duration of information delivery were as per the schedule of the cropping calendar and importance of the practices.
The respondents were of the perception that a dedicated mobile phone application (mobile app) could provide the required information in time. The app should contain dynamic information along with static content. Further, the respondents indicated the type of content required and format of delivery through the mobile app (Table-4). The respondents (86\%) were of the view that input requirements, feed rationing, assessment of pond stock and water quality corrections/amendments are to be provided in the form of calculators. For example, if a farmer gives average body weight, stocking density and survival percentage then the calculator should provide the biomass available in the pond, feed requirement and amount of feed to be given at different intervals of

Table 3 .

Information Needs of Farmers and Format of Delivery through Mobile Phones

\begin{tabular}{|c|l|l|l|c|}
\hline $\begin{array}{c}\text { S1. } \\
\text { No. }\end{array}$ & \multicolumn{1}{|c|}{ Information needed } & \multicolumn{1}{|c|}{ Format } & \multicolumn{1}{c|}{$\begin{array}{c}\text { Period \& } \\
\text { Frequency }\end{array}$} & $\begin{array}{c}\text { \% of } \\
\text { responses } \\
\text { (N=310) }\end{array}$ \\
\hline 1 & Pond preparation protocols & $\begin{array}{l}\text { Interactive Voice } \\
\text { Response (IVR) \& } \\
\text { Graphical User } \\
\text { Interfaces (GUI) }\end{array}$ & $\begin{array}{l}\text { 15th January } \\
\text { once in two days; } \\
15 \text { th July to 30th } \\
\text { August. }\end{array}$ & 77.35 \\
\hline 2 & $\begin{array}{l}\text { Seed availability, sources, } \\
\text { seed selection protocols } \\
\text { and stocking density } \\
\text { requirements and nursery } \\
\text { rearing }\end{array}$ & $\begin{array}{l}\text { IVR \& GUI } \\
\text { 1st Feb to 15th } \\
\text { March once in two } \\
\text { days; 1st August } \\
\text { to 30th August. }\end{array}$ & 74.50 \\
\hline 3 & $\begin{array}{l}\text { Feeding, water quality } \\
\text { parameters and disease } \\
\text { preventive measures }\end{array}$ & IVR \& GUI & $\begin{array}{l}15 \text { th March to } \\
\text { a week; } 1 \text { st August } \\
\text { to 15th December. }\end{array}$ & 64.65 \\
\hline
\end{tabular}


Information Seeking Behaviour of Shrimp Farmers and their Perception towards Technology Dissemination through Mobile Phones

\begin{tabular}{|c|c|c|c|c|}
\hline $\begin{array}{l}\text { S1. } \\
\text { No. }\end{array}$ & Information needed & Format & $\begin{array}{l}\text { Period \& } \\
\text { Frequency }\end{array}$ & $\begin{array}{c}\% \text { of } \\
\text { responses } \\
(\mathrm{N}=310)\end{array}$ \\
\hline 4 & $\begin{array}{l}\text { Sampling, growth } \\
\text { assessment, Feeding, } \\
\text { water quality parameters } \\
\text { and disease preventive } \\
\text { measures }\end{array}$ & IVR \& GUI & $\begin{array}{l}\text { 1st April to } 15 \text { th } \\
\text { June once a week; } \\
\text { 15th September to } \\
\text { 15th December. }\end{array}$ & 78.20 \\
\hline 5 & $\begin{array}{l}\text { Market intelligence and } \\
\text { price information }\end{array}$ & IVR \& GUI & $\begin{array}{l}\text { 1st May to } \\
30 \text { th June once } \\
\text { in week; } 1 \text { st } \\
\text { November to } 15 \text { th } \\
\text { December. } \\
\end{array}$ & 80.45 \\
\hline 6 & $\begin{array}{l}\text { Harvest and post-harvest } \\
\text { measures }\end{array}$ & IVR \& GUI & $\begin{array}{l}1 \text { st June to } \\
15 \text { th July once } \\
\text { in a week; } 15 \text { th } \\
\text { November to } 30 \text { th } \\
\text { December. }\end{array}$ & 62.70 \\
\hline
\end{tabular}

Table 4.

Preferred Features of a Mobile Application (Mobile app) on Shrimp Farming

\begin{tabular}{|c|l|l|c|}
\hline $\begin{array}{c}\text { S1. } \\
\text { No. }\end{array}$ & \multicolumn{1}{|c|}{ Content } & \multicolumn{1}{|c|}{ Format } & $\begin{array}{c}\text { \% of } \\
\text { responses } \\
\text { (N=310) }\end{array}$ \\
\hline 1 & $\begin{array}{l}\text { Better management } \\
\text { practices of farming }\end{array}$ & Text with photographs and FAQs & 72.50 \\
\hline 2 & $\begin{array}{l}\text { Feed quality \& rationing } \\
\text { management. }\end{array}$ & $\begin{array}{l}\text { Arithmetic calculations for optimal } \\
\text { use of inputs }\end{array}$ & 86.25 \\
\hline 3 & $\begin{array}{l}\text { Input requirement \&Water } \\
\text { quality amendments }\end{array}$ & $\begin{array}{l}\text { Optimum and corrections for sub } \\
\text { optimal conditions in text and } \\
\text { photographs }\end{array}$ & 78.60 \\
\hline 5 & $\begin{array}{l}\text { Health management \& } \\
\text { disease diagnosis }\end{array}$ & $\begin{array}{l}\text { Probable disease diagnostic } \\
\text { module with symptoms and } \\
\text { management measures }\end{array}$ & 81.53 \\
\hline 6 & $\begin{array}{l}\text { Feedback and interaction } \\
\text { with technical experts }\end{array}$ & $\begin{array}{l}\text { Risk assessment module in an on- } \\
\text { line questionnaire mode. }\end{array}$ & 67.05 \\
\hline
\end{tabular}


Journal of Extension Education

\begin{tabular}{|c|l|l|c|}
\hline $\begin{array}{c}\text { S1. } \\
\text { No. }\end{array}$ & \multicolumn{1}{|c|}{ Content } & Format & $\begin{array}{c}\text { \% of } \\
\text { responses } \\
\text { (N=310) }\end{array}$ \\
\hline 7 & $\begin{array}{l}\text { Quality input source and } \\
\text { market information }\end{array}$ & $\begin{array}{l}\text { Market information and technical } \\
\text { advisories in text }\end{array}$ & 73.60 \\
\hline 8 & Govt. regulations, schemes & $\begin{array}{l}\text { Guidelines and other Institutional } \\
\text { schemes in text }\end{array}$ & 65.40 \\
\hline
\end{tabular}

the day. Dynamic disease diagnostic and management module and time specific advisories $(82 \%)$, production phase wise risk assessment module (67\%), package of practices in the form of Frequently Asked Questions (FAQs) (72.50\%) and a dynamic module of inputs sources with phone numbers and market intelligence (74\%) might be the features of the mobileapp, the farmers expressed. The most important feature emphasized by the respondents $(78.80 \%)$ was that the app should have a post-a-query option to send queries to the host institution and it should be answered in two working days. Similarly it was opined that farmers can share their experiences and views on farming issues through this option.

\section{CONCLUSION}

The study has indicated that shrimp farmers perceived mobile phone as a tool for capacity development and extension services in shrimp farming. It is suggested that a dedicated mobile app having dynamic disease diagnostics, FAQs and farm inputs calculation modules with the scope for two way interaction would enhance information access. Therefore, it is high time the brackishwater aquaculture institutions develop and launch mobile apps on shrimp aquaculture.

\section{REFERENCES}

Anbarasan \& Karthikeyan, C. (2014).

Evaluating the Effectiveness of 'e-velanmai' (e-agriculture) Model of Extension through Mobile Telephony, Trends in Biosciences 7(19), 28702873 pp.

Dileepkumar, G. (2012). ICT Innovations for Agriculture and Rural Development. Presented in Proceedings 8th Convention of Grameen Gyan AbhiyanRural Knowledge Movement, M.S. Swaminathan Research foundation, Chennai, October 28-29, 2012.

Ganesan, M., Karthikeyan, K., Prashant, S \& Umadikar, J. (2013). Use of mobile multimedia agricultural advisory systems by Indian farmers: Results of a survey, Journal of Agricultural Extension and Rural Development, 5 (4), 89-99. 
Jayanthi, M. \& Ashokan, M. (2016) Constaints faced by M-Kisan users Journal of Extension Education, 28 (1), doi : http://dx.doi.org/10.26725/ JEE.2016.1.28 5622-5624

Kumaran,M., Krishnan, M \& Ravichandran, P. (2007). Extension Services in Coastal Aquacultrure : Need For a Public and Private Partnership, Indian Journal of. Fisheries, 54(1), 75-83.

Mruthunjaya \& Adhiguru, A. (2005). ICT for livelihood security: a realitycheck. Mainstreaming ICTs 2(2), 14-18.

NSSO.(2005). Situation Assessment Survey of Farmers. Report No.499(59/33)2. Government of India New Delhi.

Omotesho, K. F., Ogunlade, I \& Ayinde, O. E. (2015). Analysis of farmers' perception of the accountability of agricultural extension services in Oyo State, Nigeria. Sarhad Journal of Agriculture, 31(2), 94-100.
Osondu, C. K \& Ibezim, G. M. C. (2015). Awareness and Perception of Farmers to the Use of Information and Communication Technologies (ICTs) in Agricultural Extension Service Delivery: A Case Study of Imo State, Nigeria, International Journal of Agriculture Innovations and Research, 4(1), 55-60.

Planning Commission, Govt. of India. (2007). Recommendations of Working Group on Agricultural Extension for Formulation of Eleventh Five Year Plan (2007-12), Planning Commission, Government of India, New Delhi. http://planning commission.nic.in/ plans/planrel/11thf.htm.

Swathilekshmi, P.S., Chandrakandan, K \& Balasubramani, N. (2008), Information Utilization Behaviour and Constraint Analysis among Shrimp Farmers. Indian Journal of Social Research, 49(3),265-272. 